\title{
DIMENSIONAL, OSMOTIC, AND CHEMICAL CHANGES OF ERYTHROCYTES IN STORED BLOOD. IV. CELLS SEPARATED FROM PLASMA ${ }^{1}$
}

\author{
By S. RAPOPORT \\ WITH THE TECHNICAL ASSISTANCE OF MARY WING \\ (From the Children's Hospital Research Foundation and the Department of Pediatrics, Uni- \\ versity of Cincinnati College of Medicine, Cincinnati)
}

(Received for publication August 31, 1946)

The possibility of utilizing erythrocytes remaining after the removal of plasma has been of increasing interest in the last years with the expanding use of plasma and its derivatives and with better understanding of the clinical use of red cells. Although several reports of the large-scale use of resuspended cells are available ( 1 to 9 ), only scant information exists on in vitro changes taking place in separated red cells during storage in the packed state or in resuspension. The present study, part of an investigation dealing with in vitro changes of stored blood, is concerned with dimensional, osmotic, and chemical changes of separated cells. In view of the fact that the American Red Cross during the war collected blood in simple citrate solution as well as in ACD solution, depending on whether the blood was to be used as such or for the preparation of plasma, both types of cells, those derived from bloods collected in simple citrate solution and those from bloods collected in ACD solution, were studied. The purposes of the study may be defined as follows: (1) to establish the validity of in vitro testing of separated red cells and (2) to delimit, if possible, the optimum conditions of storage and the best type of resuspension fluid for separated cells. In most instances the report will be limited to a presentation of changes of 4 indices of blood preservation: (1) hemolysis in 0.6 per cent $\mathrm{NaCl}$ solution, (2) changes in cellular thickness, (3) adenosine triphosphate content, and (4) glycolyzing power of erythrocytes. Complete measurements of dimensional changes, including diameter, surface and volume; of the osmotic behavior; and of the phosphorus and cation distributions were performed as described in the first paper of this series (10), but are omitted here

1 The work described in this paper was done under a contract, recommended by the Committee on Medical Research, between the Office of Scientific Research and Development and the Children's Hospital of Cincinnati. for the sake of conciseness. The results of these studies in all instances supplemented and confirmed the data to be reported.

\section{METHODS}

Bloods were collected at the Blood Bank of the Cincinnati General Hospital in a manner earlier described (10). They were centrifuged, the plasma separated 24 hours after collection, and the blood cells promptly resuspended in an equal volume of resuspension fluid. After mixing they were distributed into a series of vials and stored at $4^{\circ} \mathrm{C}$. until the time of testing. In the experiments on preservation of cells stored in the packed state, the packed cells were left undisturbed until immediately prior to testing, when they were diluted with an equal volume of 0.9 per cent $\mathrm{NaCl}$ solution. A series of 16 bloods were collected in the Blood Bank of the American Red Cross in Indianapolis, resuspended in the Lilly Research Laboratories, and shipped to Cincinnati by Railway Express. This series of experiments was undertaken in order to test the preservation of red cells under actual conditions of practice. Since the bloods did not differ significantly from those studied under laboratory conditions, results on them were combined with the other data. A list of the principal resuspension fluids used is given in Table I. The fluids were made up in such a way

TABLE I

Composition of mixtures for the resuspension of blood cells

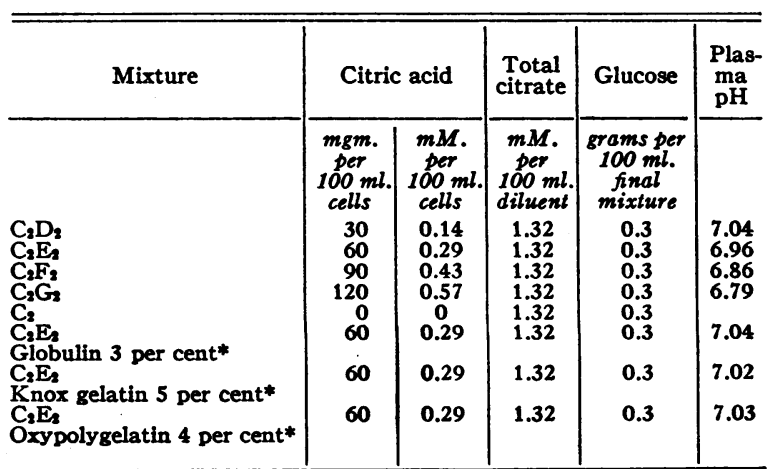

The mixtures were made up with $80 \mathrm{ml}$. of 0.9 per cent $\mathrm{NaCl}$ and sufficient water to give a final volume of $100 \mathrm{ml}$. They were added in equal volume to separated blood cells. * These products were brought to a $\mathrm{pH}$ of 7.0 by additions of $\mathrm{NaOH}$ or $\mathrm{HCl}$ before they were mixed with the other ingredients of the preservative solutions. 
as to keep the final concentration of total citrate and of dextrose constant after mixture with blood, while varying the proportions of citric acid and of trisodium citrate. The amount of citric acid was adjusted in such a manner as to cover the range between $\mathrm{pH}$ of 6.80 and 7.05 in the suspension after mixture with the red cells, taking into account the buffering properties of hemoglobin, the amount of lactic acid formed before resuspension, and the absence of plasma buffers. Colloids, where added, were brought to a $\mathrm{pH}$ of 7.0, which is close to the $\mathrm{pH}$ of the resuspended blood cells themselves, before they were mixed with the other ingredients of the preservative solutions. This was an important consideration, in view of the fact that the various products had varying initial $\mathrm{pH}$ values, $7.44,6.74$, and 5.63 , for the globulin, gelatin, and oxypolygelatin preparations, respectively. Also their buffering powers varied considerably. A number of other resuspension fluids were prepared and tested but are omitted from this list since they did not differ significantly in their characteristics from the series tabulated.

\section{RESULTS}

\section{"Spontaneous" hemolysis of resuspended cells}

The measurement of so-called spontaneous hemolysis (hemolglobin in the supernatant fluid after centrifugation), used as a measure of blood preservation by some observers (11 to 14), appeared of particular interest in view of earlier indications that this test may give results in disagreement with other indices of preservation in bloods stored in solutions entailing great dilution or in suspensions of separated blood cells. In Figure 1 is presented graphically a comparison of "spontaneous" hemolysis with that in 0.9 per cent $\mathrm{NaCl}$ solution for erythrocytes stored as whole blood in various mixtures entailing less than 25 per cent dilution and for erythrocytes in resuspension. It may be seen that for whole blood both measurements usually gave comparable results, as indicated by the tendency of the values to group themselves around the diagonal line, while the values for all cell suspensions were above the diagonal, indicating that "spontaneous" hemolysis was much less than hemolysis in 0.9 per cent $\mathrm{NaCl}$ solution. It may be recalled that in earlier papers a general parallelism between hemolysis in various concentrations of $\mathrm{NaCl}$, including 0.9 per cent $\mathrm{NaCl}$ solution and other indices of blood preservation, was demonstrated. Under the conditions described here, in resuspended cells, no correlation is found between "spontaneous" hemolysis, on the one hand, and hemolysis in 0.9 per cent $\mathrm{NaCl}$ solution or any of the

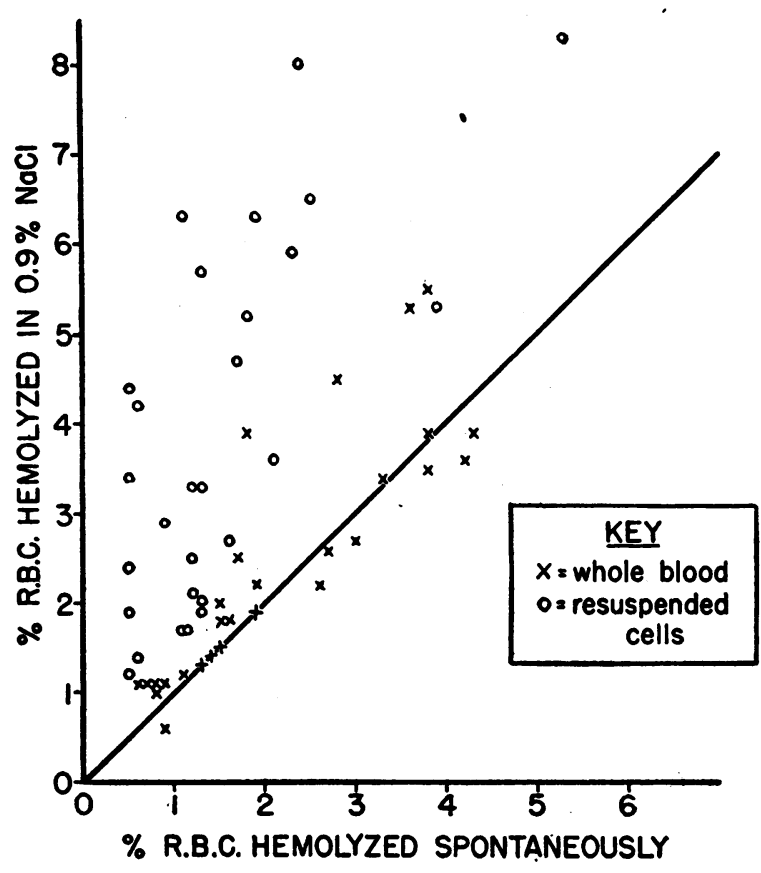

Fig. 1. Comparison of Spontaneous Hemolysis and Hemolysis in 0.9 Per Cent NaCl Solution of Resuspended Cells and of Whole Blood

other criteria of blood preservation, on the other. Spontaneous hemolysis under such circumstances is a fallacious index of the state of the red cell.

\section{Optimal acidity of resuspension fluids}

The beneficial effect of acidification of whole blood to a $\mathrm{pH}$ of about 7.0 on the preservation of erythrocytes has been established. Experiments were therefore undertaken to define the optimal amount of acid to be used in the resuspension of "citrate" cells and "ACD" cells, that is, cells derived from blood collected in simple citrate and ACD mixtures, respectively. The suspension fluids, designed to produce acidification to a varying degree and the $\mathrm{pH}$ values measured after suspension of the red cells, are listed in Table I. In the left-hand side of Figure 2 are presented data on the hemolysis in 0.6 per cent $\mathrm{NaCl}$ solution, cellular thickness, and adenosine triphosphate content of 2 suspensions of "citrate" cells after 15 days of storage. These indices are plotted against the amounts of citric acid added. It would appear from the data that 30 to $75 \mathrm{mgm}$., that is, 0.14 to $0.35 \mathrm{mM}$. of citric acid per $100 \mathrm{ml}$. of cells, provide optimal acidity for the resuspension of "ci- 

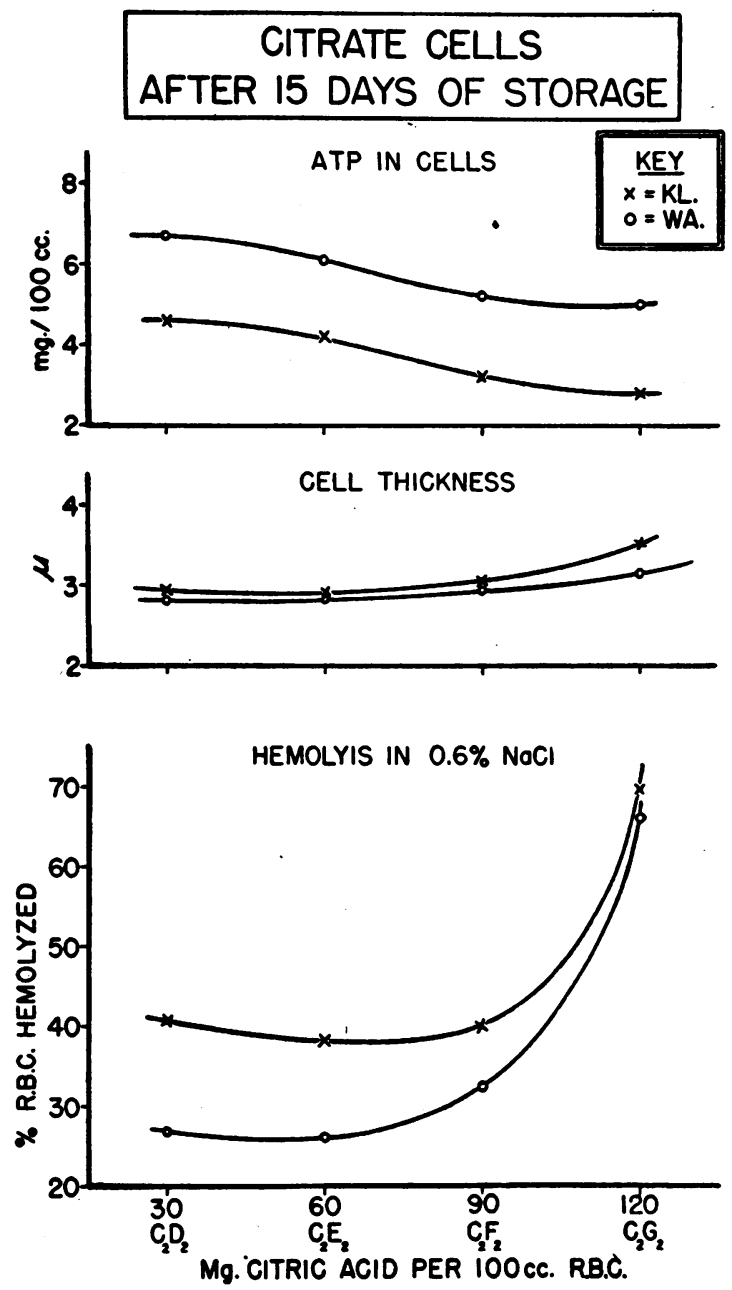

Fig. 2. Changes in 3 Indices of "Citrate" and "ACD"
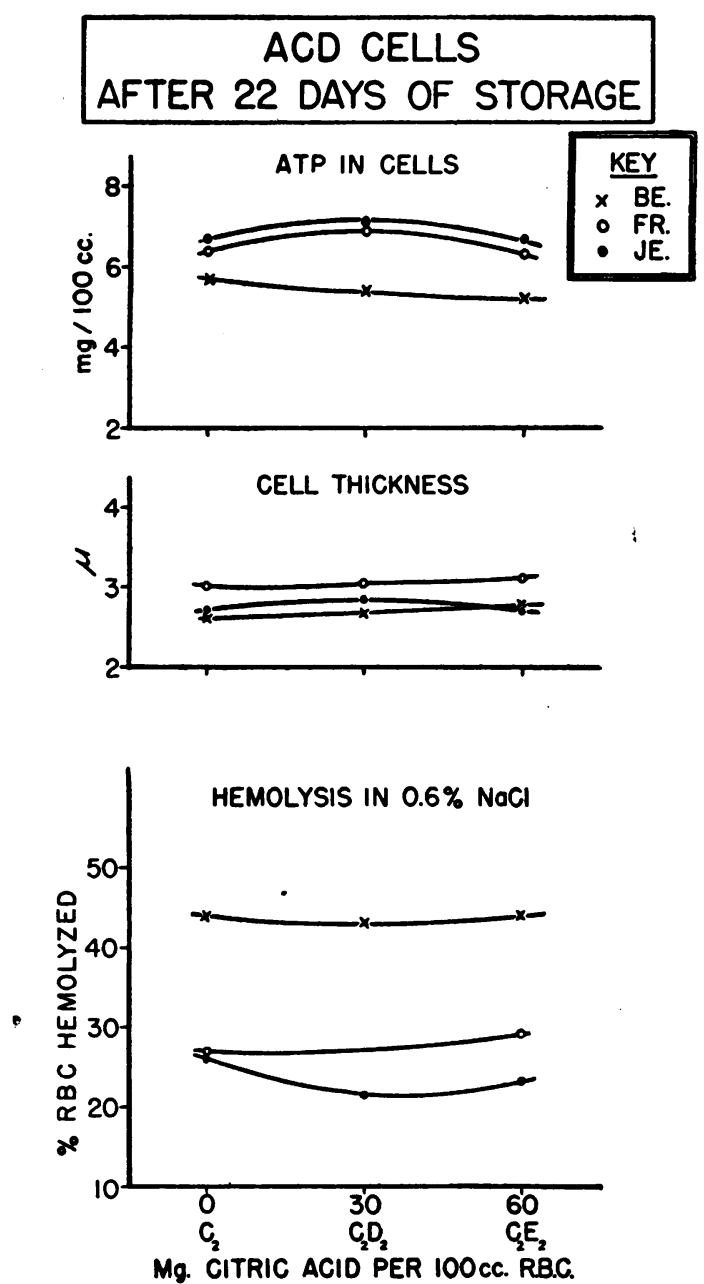

Cells Resuspended in Solutions of Varying Acidity trate" cells, while greater acidification has deleterious effects.

In the right-hand side of the same figure is presented a similar experiment designed to establish the optimal amount of acid for the resuspension of "ACD" cells. It is apparent that there was no significant difference in the preservation of red cells over the entire range of acidity studied.

\section{Comparison of cells from bloods collected in simple citrate and in $A C D$ solution}

In graphs $A$ to $C$ of Figure 3 are charted the individual data and in graph $\mathrm{D}$ the averages on the percentage of erythrocytes hemolyzed in 0.6 per cent $\mathrm{NaCl}$ solution after varying periods of storage and their regression lines. It may be seen that "citrate-cells," even if resuspended in ACD solution, were less well preserved than "ACD-cells." Data on changes in thickness, adenosine triphosphate content, glycolyzing power, and potassium content of erythrocytes, presented in a summary manner in Figure 4, confirm the conclusions based on the osmotic behavior of the red cells. In Table II are presented the numerical values for the regression equations of the 5 indices against time. It may be seen that the changes in all characteristics of the red cell progressed at their most rapid rate in citrate cells suspended in neutral solution and most slowly in ACD cells. It is noteworthy that the values of the various indices extrapolated to zero time approximated those actually observed in whole blood at the beginning of storage, indicating that the changes in resuspended cells tended to progress at an approximately linear rate. These find- 
ings support the opinion that conditions during the first 24 hours of storage are of decisive importance for the subsequent survival of red cells. The state of preservation of resuspended cells at a given time is more variable than that of whole blood, as shown by the wide scatter of points in the graphs. There is some indication, both from inspection of the data and of the errors of the regression coefficients,' that "ACD-cells" are more uniformly preserved than are "citrate-cells." Finally, it should be emphasized that all cells separated from their plasma,
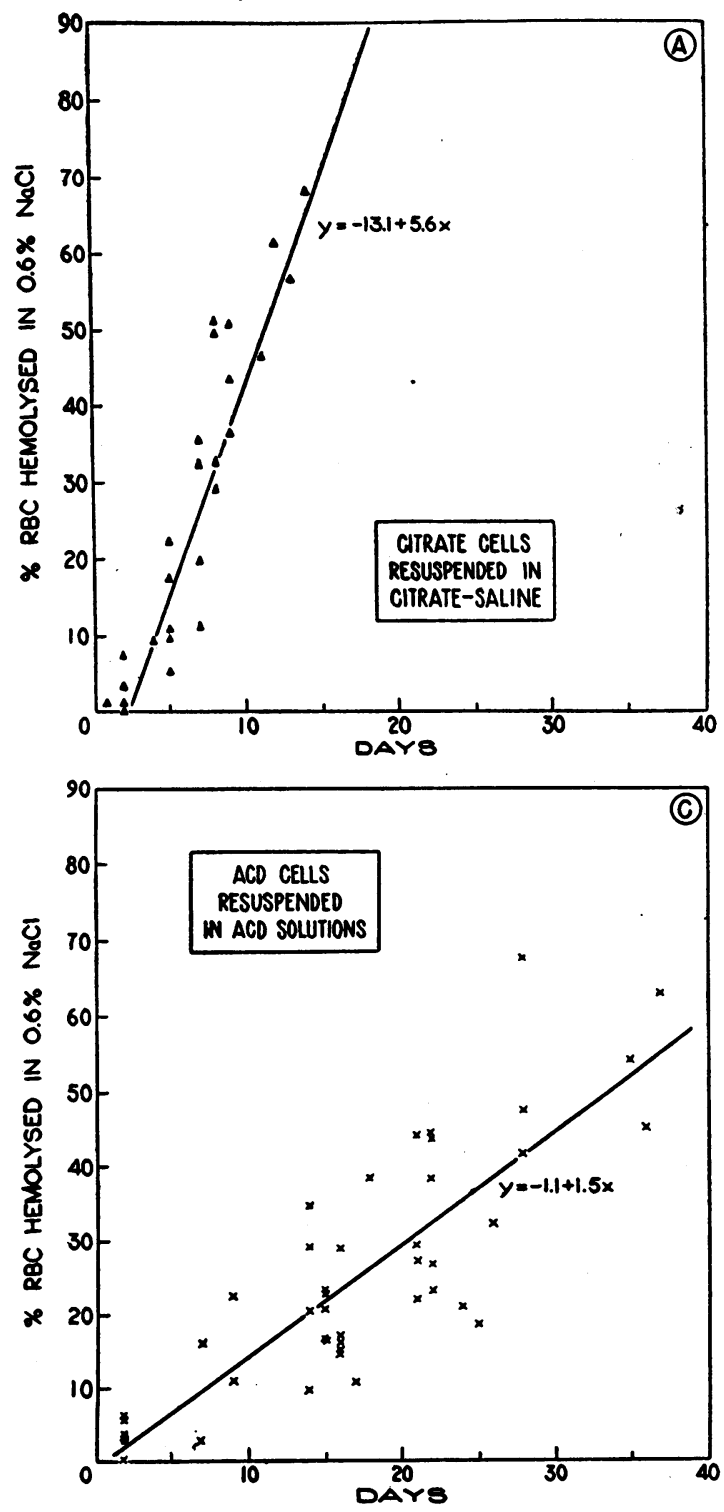

including ACD-cells, are less well preserved than those of corresponding whole bloods.

\section{Comparsion of preservation of erythrocytes stored in the packed state and in resuspension}

In Table III is presented a comparison in 2 samples of blood of the preservation of cells stored in the packed state and in resuspension, from which it may be seen that there was no significant difference in any of the indices between the 2 modes of storage.
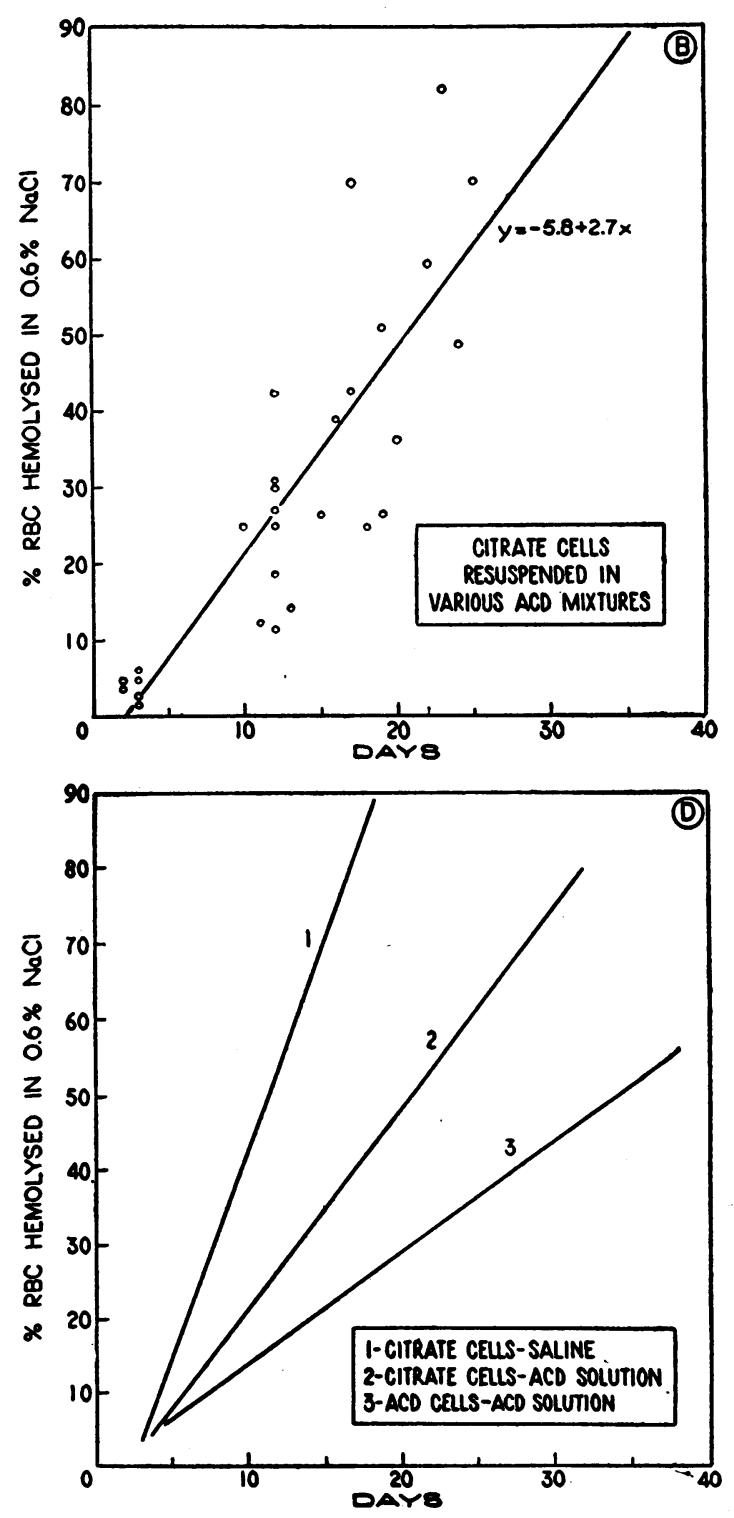

Fig. 3. Comparison with Respect to Hemolysis in 0.6 Per Cent NaCl Solution of Cells Derived from Blood Collected in Citrate and ACD Solution and Resuspended in Neutral and Acid Solutions 

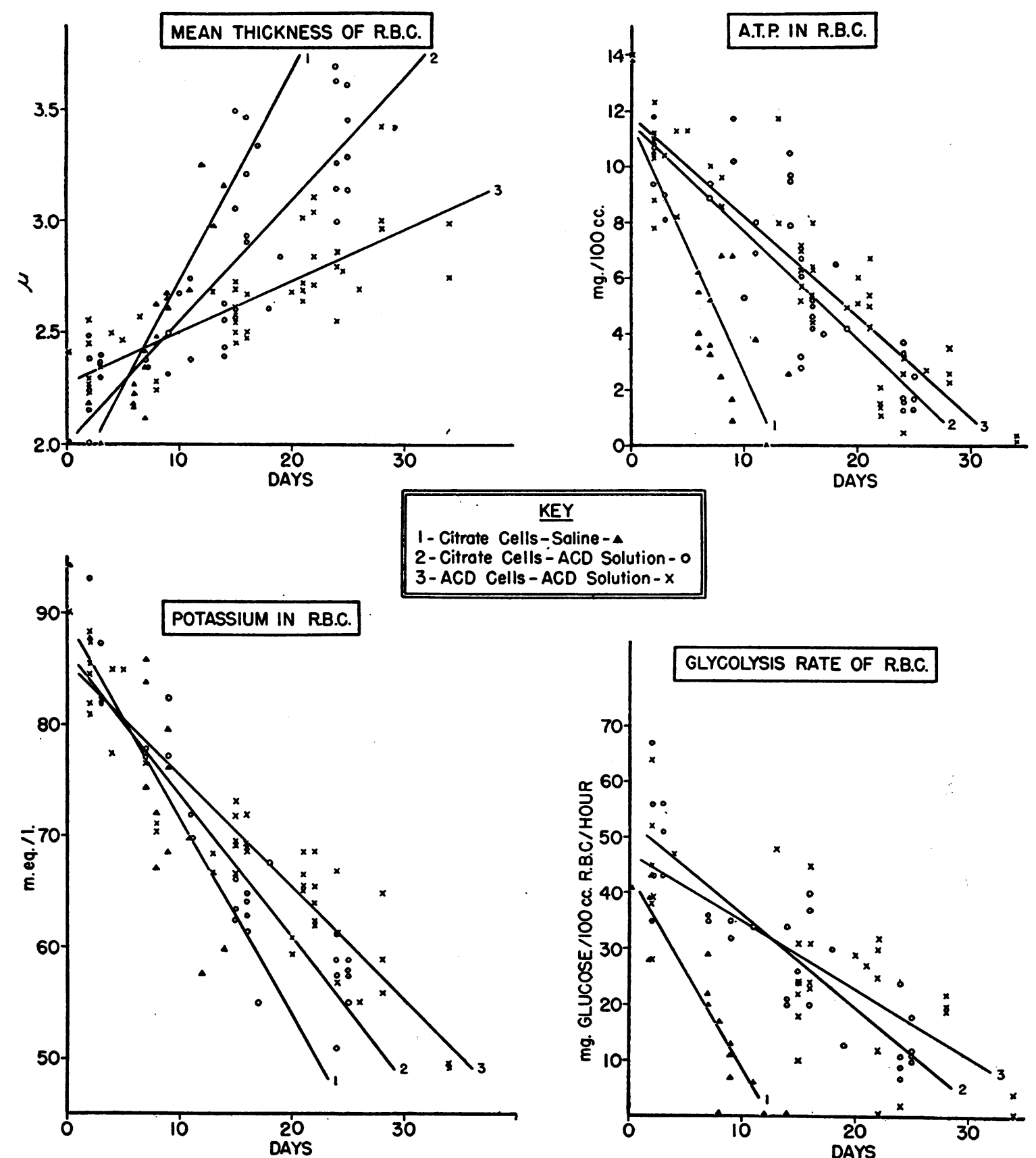

\section{KEY}

Ills - Saline -A

2- Citrate Cells - ACD Solution - 0

3-ACD Cells - ACD Solution - $x$

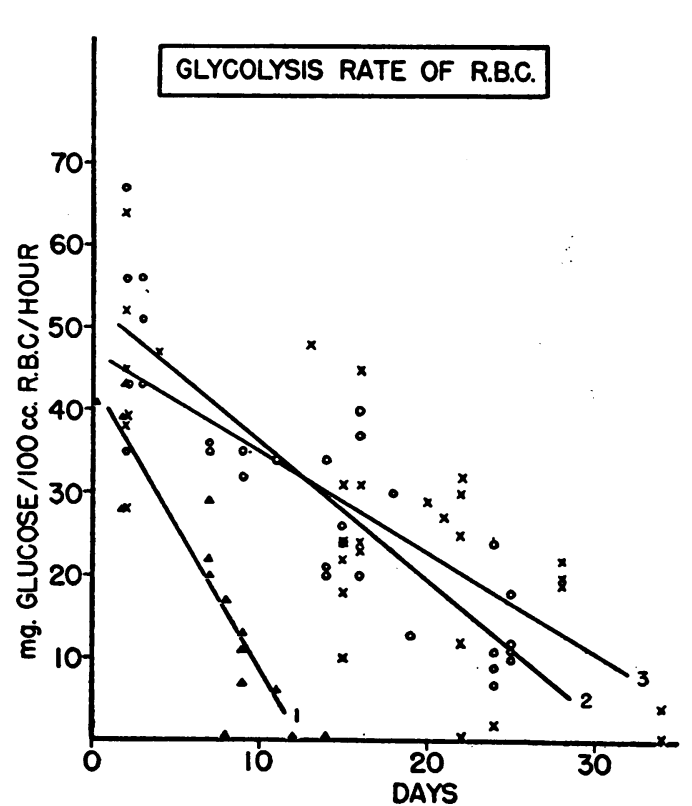

Fig. 4. Comparison of "Citrate" and "ACD" Cellls Suspended in Neutral and Acid Solution with Respect to (1) Mean Thickness, (2) Adenosine Triphosphate, (3) Potassium Content and (4) Glycolysis Rate

The effect of globulin, gelatin, and oxypolygelatin on the preservation of resuspended red cells

With the possibility in mind that the inferior preservation of separated red cells may be caused by the absence of the colloidal properties of the plasma proteins, the effect of several high-molecu- lar substances on the preservation of red cells was tested. In Table IV are presented data on an experiment carried out on 2 bloods, in which the effect of globulin (Cohn fraction IV-3, 4), gelatin (Knox P16-180) and oxypolygelatin on the preservation of "citrate" cells was compared with that 
TABLE II

Changes of 5 indices of preservation during storage of resuspended cells Regression equations and their sampling errors

\begin{tabular}{|c|c|c|c|c|c|}
\hline Cells and solution & $\begin{array}{l}\text { Hemolysis of cells in } \\
0.6 \text { per cent } \mathrm{NaCl}\end{array}$ & Cell thickness & $\begin{array}{l}\text { ATP content } \\
\text { of cells }\end{array}$ & $\begin{array}{l}\text { Glycolysis rate } \\
\text { of cells }\end{array}$ & Potassium in cells \\
\hline $\begin{array}{l}\text { Citrate-cells in } \\
\text { saline }\end{array}$ & $\begin{array}{r}\text { per cent } \\
-13.1+5.6 x \\
\pm 0.47\end{array}$ & $\begin{array}{c}\mu \\
1.77+0.095 x \\
\quad \pm 0.009\end{array}$ & $\begin{array}{c}m g m . \text { per } 100 \mathrm{ml} . \\
11.5-0.89 x \\
\pm 0.13\end{array}$ & $\begin{array}{c}m g m \text {. per } 100 \mathrm{ml} \text {. } \\
\text { per hour } \\
42.5-3.40 x \\
\pm 0.43\end{array}$ & $\begin{array}{r}\text { m.eq. per liter } \\
88.4-1.7 x \\
\pm 0.71\end{array}$ \\
\hline $\begin{array}{l}\text { Citrate-cells in } \\
\text { ACD solution }\end{array}$ & $\begin{array}{r}-5.8+2.7 x \\
\pm 0.33\end{array}$ & $\begin{array}{c}1.99+0.054 x \\
\quad \pm 0.009\end{array}$ & $\begin{array}{c}11.6-0.39 x \\
\pm 0.04\end{array}$ & $\begin{array}{c}52.7-1.66 x \\
\pm 0.16\end{array}$ & $\begin{array}{r}86.5-1.3 x \\
\pm 0.19\end{array}$ \\
\hline $\begin{array}{l}\text { ACD-cells in ACD } \\
\text { solution }\end{array}$ & $\begin{array}{r}-1.1+1.5 x \\
\pm 0.15\end{array}$ & $\begin{array}{c}2.27+0.023 x \\
\quad \pm 0.003\end{array}$ & $\begin{array}{c}11.7-0.35 x \\
\pm 0.02\end{array}$ & $\begin{array}{c}46.8-1.20 x \\
\pm 0.20\end{array}$ & $\begin{array}{r}85.5-1.0 x \\
\pm 0.05\end{array}$ \\
\hline
\end{tabular}

of a standard acid resuspension fluid. As may be seen from the data, no particular effect, favorable or unfavorable, was obtained by the addition of these materials. In other experiments not reported here, dextrin and small amounts of plasma protein in concentrations up to 1 per cent likewise failed to affect the preservation of cells.

\section{The preservation of erythrocytes centrifuged and resuspended in own plasma}

The data presented in Table $\mathrm{V}$ indicate that there was no difference in the preservation between the portion of blood that had been centrifuged and the one which had been left undisturbed, while the separated red cells showed distinctly inferior preservation. It would seem, therefore, that mechanical factors play a minor part in the determination of the preservation of the red cell.

\section{TABLE III}

Comparison of preservation of erythrocytes stored in the packed state and in resuspension

The cells studied were derived from blood collected in ACD-15 (ACD-G) solution.

\begin{tabular}{l|c|c|c|c|c|c}
\hline \hline \multicolumn{1}{c}{$\begin{array}{c}\text { Sample and } \\
\text { condition }\end{array}$} & $\begin{array}{c}\text { Stor- } \\
\text { age } \\
\text { pe- } \\
\text { riod }\end{array}$ & $\begin{array}{c}\text { Diam- } \\
\text { eter }\end{array}$ & $\begin{array}{c}\text { Thick- } \\
\text { ness }\end{array}$ & $\begin{array}{c}\text { Hemol- } \\
\text { ysis in } \\
\text { 0.6 per } \\
\text { cent } \\
\text { NaCl }\end{array}$ & ATP & $\begin{array}{c}\text { Glycoly- } \\
\text { sis rate }\end{array}$ \\
\hline & days & $\mu$ & $\mu$ & $\begin{array}{c}\text { per } \\
\text { cent }\end{array}$ & $\begin{array}{c}\text { mgm. } \\
\text { per } \\
100 \text { ml. }\end{array}$ & $\begin{array}{c}\text { mgm. per } \\
100 \text { ml. } \\
\text { per hour } \\
29\end{array}$ \\
Sm. cells & 20 & 7.2 & 2.35 & 32.3 & 5.1 & 29 \\
Sm. suspension* & 20 & 7.2 & 2.38 & 31.4 & 6.8 & 22 \\
\hline As. cells & 24 & 7.0 & 2.71 & 27.7 & 3.1 & 30 \\
As. suspension* & 24 & 7.0 & 2.80 & 27.1 & 3.5 & 31 \\
\hline
\end{tabular}

* Mixture $C_{2}$, a neutral citrate-saline-dextrose diluent, added in equal amount to the separated cells.

\section{SUMMARY}

With certain limitations in vitro testing is applicable to the study of resuspended red cells as well as to whole blood. A comparison of the changes of

TABLE IV

Effect of the addition of globulin, gelatin, and oxypolygelatin on the preservation of resuspended red cells

The cells studied were derived from blood collected in simple citrate solution.

\begin{tabular}{|c|c|c|c|c|c|c|}
\hline $\begin{array}{c}\text { Sample and } \\
\text { mixture }\end{array}$ & $\begin{array}{l}\text { Stor- } \\
\text { age } \\
\text { pe- } \\
\text { riod }\end{array}$ & $\begin{array}{l}\text { Thick- } \\
\text { ness }\end{array}$ & $\begin{array}{l}\text { Hemol- } \\
\text { ysis in } \\
0.6 \mathrm{per} \\
\text { cent } \\
\mathrm{NaCl}\end{array}$ & ATP & $\begin{array}{l}\text { Glycoly- } \\
\text { sis rate }\end{array}$ & $\mathrm{pH}$ \\
\hline Ap. $C_{2} E_{2}{ }^{*}$ & $\begin{array}{r}3 \\
11 \\
18\end{array}$ & $\begin{array}{c}\mu \\
\\
2.30 \\
2.38 \\
2.61\end{array}$ & $\begin{array}{r}\begin{array}{c}\text { per } \\
\text { cent }\end{array} \\
\\
4.9 \\
12.1 \\
24.6\end{array}$ & $\begin{array}{c}\underset{\text { mgm. }}{\text { per }} \\
100 \mathrm{ml} . \\
\\
8.8 \\
8.0 \\
6.5\end{array}$ & $\begin{array}{c}\text { mgm. per } \\
100 \text { ml. } \\
\text { of cells } \\
\text { per hour } \\
56 \\
34 \\
30\end{array}$ & $\begin{array}{l}7.04 \\
6.66 \\
6.50\end{array}$ \\
\hline $\begin{array}{l}\text { Ap. globulin } \\
3 \text { per cent } \\
\text { (Cohn Fr. } \\
\text { IV-3-4) }\end{array}$ & $\begin{array}{r}2 \\
12 \\
19\end{array}$ & $\begin{array}{l}2.37 \\
2.46 \\
2.71\end{array}$ & $\begin{array}{r}1.8 \\
10.7 \\
40.2\end{array}$ & $\begin{array}{l}9.3 \\
8.3 \\
6.4\end{array}$ & $\begin{array}{l}56 \\
27\end{array}$ & $\begin{array}{l}7.01 \\
6.61 \\
6.50\end{array}$ \\
\hline $\begin{array}{l}\text { Ap. oxypolygela- } \\
\text { tin } 4 \text { per cent }\end{array}$ & $\begin{array}{l}11 \\
19\end{array}$ & $\begin{array}{l}2.48 \\
2.68\end{array}$ & $\begin{array}{r}7.1 \\
30.0\end{array}$ & $\begin{array}{l}9.2 \\
2.4\end{array}$ & $\begin{array}{l}33 \\
17\end{array}$ & $\begin{array}{l}6.63 \\
6.50\end{array}$ \\
\hline $\mathrm{Pa} . \mathrm{C}_{2} \mathrm{E}_{2}{ }^{*}$ & $\begin{array}{r}2 \\
12 \\
19\end{array}$ & $\begin{array}{l}2.39 \\
2.74 \\
2.84\end{array}$ & $\begin{array}{r}4.8 \\
26.7 \\
50.8\end{array}$ & $\begin{array}{l}9.1 \\
6.0 \\
3.0\end{array}$ & $\begin{array}{l}51 \\
13\end{array}$ & $\begin{array}{l}7.02 \\
6.56 \\
6.44\end{array}$ \\
\hline $\begin{array}{l}\text { Pa. globulin } \\
3 \text { per cent } \\
\text { (Cohn Fr. } \\
\text { IV-3-4) }\end{array}$ & $\begin{array}{r}3 \\
11 \\
18\end{array}$ & $\begin{array}{l}2.49 \\
2.55 \\
2.88\end{array}$ & $\begin{array}{r}3.3 \\
13.0 \\
49.1\end{array}$ & $\begin{array}{l}9.0 \\
6.9 \\
4.2\end{array}$ & $\begin{array}{l}50 \\
26 \\
12\end{array}$ & $\begin{array}{l}7.02 \\
6.61 \\
6.49\end{array}$ \\
\hline $\begin{array}{l}\text { Pa. gelatin } \\
5 \text { per cent } \\
\text { (Knox P16-180) }\end{array}$ & $\begin{array}{l}11 \\
19\end{array}$ & $\begin{array}{l}2.64 \\
2.98\end{array}$ & $\begin{array}{l}11.7 \\
50.8\end{array}$ & 1.9 & 12 & $\begin{array}{l}6.59 \\
6.44\end{array}$ \\
\hline $\begin{array}{l}\mathrm{Pa} \text {. oxypolygela- } \\
\text { tin } 4 \text { per cent }\end{array}$ & $\begin{array}{l}12 \\
18\end{array}$ & $\begin{array}{l}2.68 \\
2.96\end{array}$ & $\begin{array}{l}20.4 \\
47.9\end{array}$ & 3.0 & 11 & $\begin{array}{l}6.62 \\
6.49\end{array}$ \\
\hline
\end{tabular}

* The composition of this mixture is given in Table I. 
TABLE V

The preservation of erythrocytes, centrifuged and resuspended in own plasma

The blood studied was collected in ACD solution. One portion was left undisturbed, another one was centrifuged for 2 hours and resuspended, and a third one was centrifuged, the plasma removed and replaced by an acid crystalloid resuspension solution. Measurements of preservation were carried out after 17 days of storage.

\begin{tabular}{|c|c|c|c|c|c|c|c|}
\hline \multirow[b]{2}{*}{$\begin{array}{l}\text { Condition of } \\
\text { sample }\end{array}$} & \multirow{2}{*}{$\begin{array}{l}\mathrm{Di}- \\
\text { am- } \\
\text { eter }\end{array}$} & \multirow[b]{2}{*}{$\begin{array}{l}\text { Thick- } \\
\text { ness }\end{array}$} & \multicolumn{2}{|c|}{$\underset{\text { in }}{\mathrm{Hemolysis}}$} & \multirow[b]{2}{*}{ ATP } & \multirow[b]{2}{*}{$\begin{array}{l}\text { Potas- } \\
\text { sium }\end{array}$} & \multirow[b]{2}{*}{$\mathrm{pH}$} \\
\hline & & & $\begin{array}{c}0.9 \\
\text { per } \\
\text { cent } \\
\mathrm{NaCl}\end{array}$ & $\begin{array}{c}0.6 \\
\text { per } \\
\text { cent } \\
\mathrm{NaCl}\end{array}$ & & & \\
\hline & $\mu$ & $\mu$ & $\begin{array}{l}\text { per } \\
\text { cent }\end{array}$ & $\begin{array}{l}\text { per } \\
\text { cent }\end{array}$ & $\begin{array}{l}\text { mgm. per } \\
100 \mathrm{ml} . \\
\text { of cells }\end{array}$ & $\begin{array}{c}\text { m.eq. per } \\
\text { liter of } \\
\text { cells }\end{array}$ & \\
\hline Undisturbed & 7.2 & 2.60 & 1.1 & 33.2 & 6.2 & 71.5 & 6.58 \\
\hline $\begin{array}{l}\text { Centrifuged } \\
\text { and resus- } \\
\text { pended in } \\
\text { own plasma }\end{array}$ & 7.2 & 2.65 & 1.0 & 35.7 & 6.8 & 70.4 & 6.61 \\
\hline $\begin{array}{l}\text { Resuspended } \\
\text { in crystalloid } \\
\text { solution }\end{array}$ & 6.8 & 3.11 & 2.3 & 49.1 & 4.4 & 63.2 & 6.55 \\
\hline
\end{tabular}

the various indices in vitro indicates that they maintain similar relationships with each other as they do in whole blood. Even under the best conditions the preservation of separated red cells is inferior and much more variable than that of the cells of corresponding whole blood. Cells derived from bloods collected in ACD solution are better preserved than those derived from bloods collected in citrate solution. The preservation of cells from citrate blood may be improved by resuspension in acidified solutions, but even then they are not so well preserved as ACD cells. Such data indicate that processes taking place in the first 24 hours of storage before the cells are separated have a determining influence on the course of the subsequent preservation. The optimal acidity for the preservation of citrated cells may be defined within the limits of 0.14 to $0.35 \mathrm{mM}$. of citric acid per $100 \mathrm{ml}$. of cells. ACD cells may be conveniently and advantageously stored in packed form. The cause of the inferior preservation of separated red cells is unknown at present. Addition of globulin or gela- tin products does not appear to improve their preservation.

I should like to thank Dr. C. G. Culbertson and Mrs. H. Zerfas of the Blood Donor Service of the American Red Cross in Indianapolis and Mr. W. A. Jamieson of the Lilly Research Laboratories for their cooperation in obtaining samples of blood cells.

\section{BIBLIOGRAPHY}

1. MacQuaide, D. H. G., and Mollison, P. L., Treatment of anemia by transfusion of concentrated suspensions of red cells. Brit. M. J., 1940, 2, 555.

2. Williams, G. E. O., and Davie, T. B., Preparation and use of concentrated red cell suspensions in treatment of anemia. Brit. M. J., 1941, 2, 641.

3. Watson, L., Red-cell suspension transfusions. Lancet, 1943, 1, 107.

4. Evans, R. S., The use of concentrated red cells as a substitute for whole blood in transfusion therapy of anemia. J. A. M. A., 1943, 122, 793.

5. Taylor, E. S., Thalhimer, W., and Cooksey, W. B., The organization of a red blood cell transfusion service. J. A. M. A., 1944, 124, 958.

6. Binder, M. L., and Klein, A., Concentrated red cell transfusions. Am. J. M. Sc., 1944, 208, 95.

7. Cooksey, W. B., and Horwitz, W. H., Use of salvaged red cells. J. A. M. A., 1944, 124, 961.

8. Thalhimer, W., and Taylor, E. S., The transfusion of centrifuged human type $O$ cells resuspended and stored in 10 per cent corn syrup. J. A. M. A., 1945, 127, 1096.

9. Bagdasarov, A., Blood transfusion in U.S.S.R. Brit. M. J., 1942, 2, 445.

10. Rapoport, S., Dimensional, osmotic and chemical changes of erythrocytes in stored blood. I. Blood preserved in sodium citrate, neutral, and acid citrate-glucose (ACD) mixtures. J. Clin. Invest., 1947, 26, 591.

11. De Gowin, E. L., Harris, J. E., and Plass, E. D., Studies on preserved human blood. I. Various factors influencing hemolysis. J. A. M. A., 1940, $114,850$.

12. Muether, R. O., and Andrews, K. R., Studies on stored blood. II. Effect of storage on human blood. Am. J. Clin. Path., 1941, 11, 314.

13. Alsever, J. B., and Ainslie, R. B., A new method for the preparation of dilute blood plasma and the operation of a complete transfusion service. New York State J. Med., 1941, 41, 126.

14. Kendrick, D. B., Jr., Elliott, J., Reichel, J., Jr., and Vaubel, E. K., Supply of preserved blood to European theater of operations. Bull. U. S. Army M. Dept., 1945, No. 84, 66. 